\title{
Israelis, Palestinians, and Americans: More Politics, Please, Less Process
}

\author{
IAN S. LUSTICK \\ University of Pennsylvania, United States \\ ORCID No: 0000-0001-7526-2679
}

\begin{abstract}
Once upon a time, the two-state solution to the Israeli-Palestinian conflict was a solution, a pretty picture of the future that good-hearted and moderate people could imagine as providing enough justice and satisfaction to both sides as to be achievable by bargaining in good faith and with support from the international community. It remains a pretty picture of the future, but no longer an outcome that anyone knows how to achieve. A pretty picture of the future without a plan for getting there is just that, a picture not a solution. Indeed, it has been years, perhaps decades, since the success of negotiations between Israel and the Palestinians became so utterly implausible that efforts to conduct or encourage them ceased to matter, except for the political cover that making such efforts could give to politicians and diplomats primarily interested in other things.
\end{abstract}

Keywords: Israeli-Palestinian Conflict, Peace Process, Two-state Solution, United States

Insight Turkey 2020

Vol. 22 / No. 1 / pp. 21-32 


\section{Deal of the Century?}

$\mathrm{T}$ he announcement on January 28, 2020 of the long-ballyhooed and long-delayed Trump-Kushner-Netanyahu "deal of the century" marked a change in American foreign policy, but not nearly as important a change as its critics charge or its promotors claim. The former, of course, vastly outnumber the latter. They condemn Washington's consignment of the Palestinians to be crowded into an archipelago of walled ghettos, and its public and full-throated endorsement of almost all right wing Israeli talking points. These include:

- Faulting the Arabs entirely for the conflict;

- Defining the main problem to be solved as that of guaranteeing every aspect of Israel's security;

- Treating the Palestinian-Arab refugee problem as no different from that of Jews who left Muslim countries for Israel;

- Requiring Palestinians to recognize Israel as the "nation-state of the Jewish people;"

- condemning Iran as a crazed and all-devouring menace to civilization in the Middle East;

- Stripping Palestinians of any claim to, control of, or official presence in the actual city of al-Quds (Jerusalem);

- Characterizing Hamas and all militant resistance against Israel as terrorism;

- Negating any Palestinian refugee "right of return;"

- Voiding all previous United Nations (UN) resolutions except those favoring Israel;

- Demanding that questions no longer be asked about the truth of key Zionist ideological claims;

- Requiring an end to Palestinian "incitement" against Israel, with no mention of Jewish incitement or vigilantism against Palestinians;

- Affirming the validity of Israeli legal and political claims to sovereignty over lands captured in 1967.

The Trump plan's promoters declare, in stentorian tones, that it provides the first realistic "vision" for a twostate solution and detailed path to its realization, with Israel and Palestine living side by side in peace, security, and mutual prosperity. It is, they say, an arduously and expertly prepared blueprint arrived at through dogged efforts and years of negotiations.

Of course, the negotiations never took place between Israel and the Palestinians, or between the United States and the Palestinians. They were overwhelmingly the product of consultations between a fervently committed array of right wing Zionist officials in Washington and an unprecedentedly right wing government in Israel. It is entirely unsurprising that the participants in these "negotiations" whose political and ideological commitments are so closely aligned could come to an agreement that could be celebrated at the White House in a campaign-like rally atmosphere. It is even less surprising when one considers that both of the event's main attractions -Donald Trump and Benjamin Netanyahu- were fac- 
ing political and legal threats capable of ending their careers.

On the other hand, most critics of the "no-deal" deal are also mischaracterizing it. Yes, it is a transparent fake. It offers "a two-state solution" by demarcating the creation (within the borders of sovereign Israel or of Israeli military control) of a glorified Birobidzhan the "Jewish Autonomous Region" created by Stalin in 1934 as a Jewish homeland on the Soviet-Chinese border. Even this partially "sovereign" state of Palestine, this "state minus," as Netanyahu has called it, is not actually achievable until such time as a long list of unperformable Palestinian requirements is met. For all this, and more, it deserves, and will receive, intense criticism and even ridicule.

But there is one charge most proponents of the two-state solution who criticize the plan have no right to make. The Trump plan is no phonier, and no more a pretense of being something it is not, than the years of empty talk about advancing two-state negotiations between Israel and the Palestinians.

The real need now is for a new way to think, not about how the land between the Jordan and the Mediterranean can be agreeably divided, but how the one state, Israel, that rules all the people and regions in that territory, can be transformed and democratized. In other words, both the promoters and the critics of the Trump plan remain captive to an outmoded, politically and intellectually
The assumption that the

West Bank and Gaza are not,

already, fully incorporated

into the power field of the

Israeli state, and that therefore

a separation between "Israel"

and "territories occupied by

Israel" can still transpire as

the result of negotiations, is

fundamentally wrong

disorienting "two-state solution" paradigm. The assumption that the West Bank and Gaza are not, already, fully incorporated into the power field of the Israeli state, and that therefore a separation between "Israel" and "territories occupied by Israel" can still transpire as the result of negotiations, is fundamentally wrong. This false assumption serves as a frame of reference forcing those who use it to adopt false beliefs, and to say false things about the world and about what they are doing. It also allows and even encourages them to pursue objectives (alleviation of anxiety, emotional satisfaction, political convenience, economic profit, or organizational survival) disconnected from, and counterproductive for, improving the lives of both Jews and Palestinians.

\section{How Did We Get Here?}

To appreciate how desperately the problem needs to be re-understood 
from dividing the country to transforming the kind of state that rules it, consider this abbreviated chronicle of diplomacy intended to achieve partition.

In the late 1960s and early 1970s, most Israelis were flying high, thinking they could have all the territory captured by their army in the 1967 war and ignore the Palestinians. Efforts by some Palestinians and Israelis to move toward a solution based on establishing a Palestinian state alongside Israel in the West Bank and Gaza Strip went nowhere. Most Palestinians still did not accept the strategic necessity or possibility of compromise with the "Zionist entity." Most Israelis felt the same way. Why compromise with an enemy when you don't have to? Israel's quick defeat of incipient revolts by Fatah and other Palestinian organizations, and the painful casualties inflicted on the Jewish state during the War of Attrition with Jordan and Egypt (1969-1970), and especially the in the 1973 War changed things -for the Palestinians, for the Arabs, and for Israeli Jews. Indeed, we can mark disengagement talks between Egyptians and Israelis at Kilometer 101 in the Sinai, on October 27, 1973, as the real beginning of what we have for so long referred to as the "peace process."

Since then we have had a world of process, but very little peace. In October 1973, disengagement talks led to the short-lived, U.S.-Soviet convened Geneva Conference, followed by Henry Kissinger's shuttle diplomacy, between 1973-1975. Despite initial

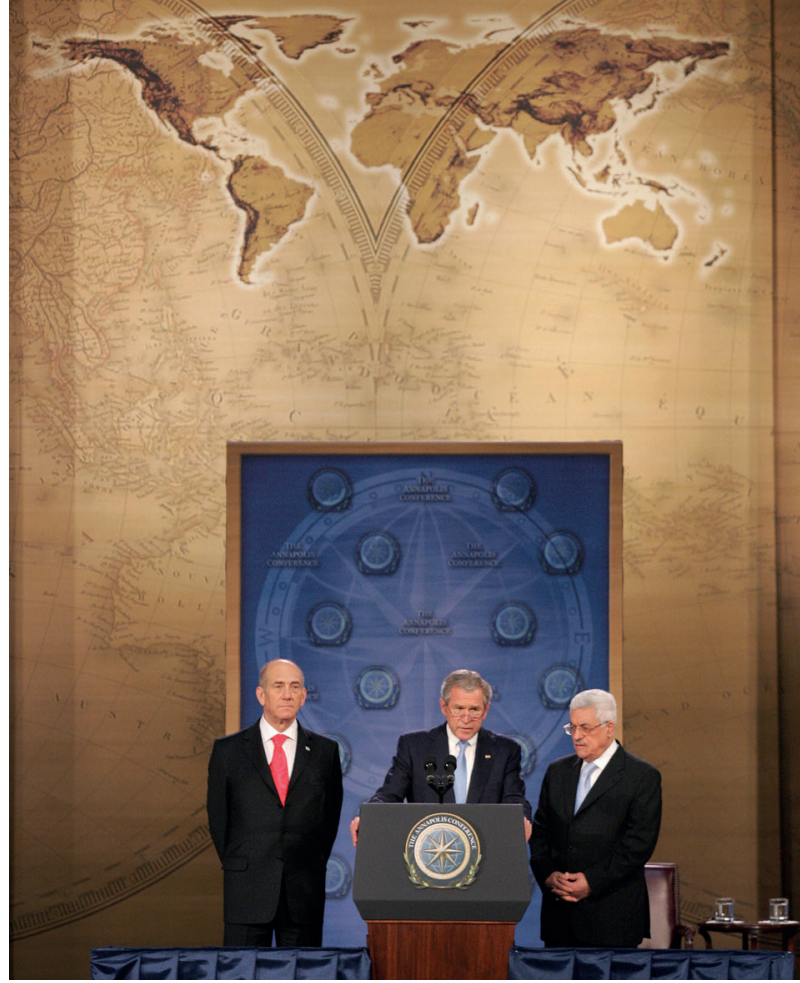

U.S. President George W. Bush speaks with Israel's Prime Minister Ehud Olmert and Palestinian Authority President Mahmoud Abbas during the Annapolis Conference, in the United States, November 27, 2007.

SAUL LOEB / AFP via Getty Images

attempts by Nixon to include Jordan in the disengagement negotiations, Kissinger skirted the West Bank issue, going so far as to give future Israeli governments a veto over U.S. contacts with the Palestine Liberation Organization (PLO). From 1977 to 1981 the peace process (including Sadat's visit to Israel, the Camp David Summit hosted by President Jimmy Carter, and the ill-fated "Autonomy Negotiations,") was conducted within the framework of the Camp David Accords. Fruitless negotiations, thoroughly exploited by the Begin government, revealed that the idea of "full autonomy" for the Palestinians was simply a fig-leaf to camouflage Israeli settlement and absorption of 
the West Bank while consolidating a separate peace between Israel and Egypt. In the aftermath of the first Lebanon War, the Reagan Initiative was launched, pointed toward some arrangement with Jordan entailing an end to Israeli occupation of Palestinian areas. That fizzled, leading to frantic and complicated efforts during the Peres-Shamir national unity government in the mid-1980s to arrange a Jordan-option centered negotiating process. After that effort's collapse, and the outbreak of the First Intifada, Secretary of State Shultz's Plan of 1988 took the stage, followed by the Shamir Plan of 1989, neither of which went anywhere. After the Gulf War in 1991, President George H. W. Bush convened the Madrid conference, which aimed at a comprehensive peace. That process staggered on to an inconclusive, ignominious end by 1994 .

Meanwhile Israelis and Palestinians had begun what became known as the "Oslo Process." From 1993 to 1999 that process achieved significant gains, including Israeli withdrawals from small portions of the West Bank and Gaza and the relocation of PLO officials to those territories. But Israeli government timidity, ferocious opposition from rejectionists on both sides, Rabin's assassination, constantly escalating settlement activity, calculated sabotage by the first Netanyahu government, Ehud Barak's hubristic errors, and President Clinton's diplomatic ineptitude, produced Oslo's effective collapse following the Camp David Summit in 2000 and the outbreak of the Second Intifada. In
The idea of "full autonomy" for the Palestinians was simply a fig-leaf to camouflage Israeli settlement and absorption of the West Bank while consolidating a separate peace between Israel and Egypt

2002, President George W. Bush announced his own two-state solution initiative known as the "Road Map to Peace." Desultory talks continued within this framework through the Sharm el-Sheikh Summit of 2005, Israel's unilateral disengagement and blockade of Gaza in 2006, the second Lebanon War in that same year, and the Annapolis Peace Conference of 2007, featuring talks between Prime Minister Ehud Olmert and Palestinian National Authority president Mahmoud Abbas. In the wake of their failure, President Obama appointed George Mitchell as his special envoy for Middle East peace. Mitchell oversaw intensive but fruitless negotiations among Israelis, Palestinians, and Americans from 2009 to 2011. Within two years after Mitchell resigned in 2011, Secretary of State John Kerry launched his initiative, with Martin Indyk acting as special envoy a frenzied but failed diplomatic effort that lasted from 2013 through 2014. Most recently, of course, we have seen three years of effort by the Trump Administration, via Jared Kushner, Jason Greenblatt, and Avi Berkowitz, to continue the process. 
Instead of obsessing about

how to reach an agreement between Jews and Palestinians

in two states that will never

exist, those in Washington,

Europe, and the Middle East

who care about the problem

should focus on how, even

over generations, to achieve

equality between Jews and

Palestinians in the one state

-Israel- that does exist
With this record in mind, one can be forgiven for doubting that peace "process" is the correct term. A "process," by definition, leads from one place or state of affairs in a sequence, however direct or indirect, toward a desired or at least a different outcome. A process, in other words, includes both movement and direction. What we can see across the decades is a great deal of movement, but no direction. What we have here, in other words, is not a process at all but a carousel, not a journey from war to peace, but a merry-go-round of endless motion, leading nowhere.

\section{Past the Point of No Return}

However, for all the running in place, there is one thing that has changed, one measure of "progress" toward a destination that is unmistakable - that is the steep, steady, and seemingly irresistible upward slope of the line tracing the number of Jewish settlers living across the Green Line. In the early 1980s, Meron Benvenisti, along with planners within the Israeli government and the Jewish Agency's Land Settlement Department, identified 100,000 settlers as the "point of no return" beyond which Israel would permanently lose the option to withdraw. Including the settlements in expanded East Jerusalem, more than six times that number of Jews now live in occupied territory -equal to almost 10 percent of Israel's Jewish population. The settlements are only one factor, but they are a major factor, in understanding why the twostate idea has been a "dead solution walking" for at least a decade. The deeper reason is that Israeli politics have shifted so far and so broadly to the right, that no decision to allow a viable Palestinian state can even be considered by ambitious Israeli politicians, let alone implemented by an Israeli government. This is the result of years of fury and frustration with Palestinians, a Holocaustia mentality that imagines that for Jews it is always 1938, and that all non-Jews are at any time liable to show their Nazi side; and the effectively infinite aid provided to Israel by the United States, which incentivized Israeli extremism and destroyed the political careers of countless Israeli pragmatists. That a viable Palestinian state will not be established in the West Bank via negotiations is a reality that can no longer be plausibly denied. It is no longer feared by its opponents, nor genuinely expected by its advocates. 
However, different the Trump plan may be from previous plans such as "the Clinton Parameters" or the "Road Map," the Trump plan is similar, not only in its disingenuous endorsement of the two-state solution, but in what will happen as a result of this most recent "peace process" episode. As we have seen in the past, so shall we see in the future:

- Non-implementation of a much publicized plan of action;

- Ever-deepening Israeli control over Palestinian lives;

- Israeli governments blaming Palestinians for never missing an opportunity to miss an opportunity;

- Palestinians blaming Israelis for always disguising devices for Israeli expansion or domination as opportunities;

- Zero progress toward a two-state solution, but eventual efforts, by a future American administration, to take yet another ride on the peace process merry-go-round.

By announcing a two-state solution when they are, in fact, dancing on its grave, Trump, Kushner, and Netanyahu believe they are preserving the "Jewish state" from political miscegenation. What they do not realize is that by accelerating Israeli annexation even of parts of the West Bank, they are helping to launch a long-term process that will, jaggedly but ineluctably, lead to the end of the "Jewish state." According to Israeli army figures, there are already more Arabs living between the Jordan River and the Mediterranean Sea than there are Jews. Ruled effectively, if not officially, by the same state, all these people -Jews, Arabs, and non-Jewish non-Arabs- will eventually be represented by the same state that rules them. Slow, bloody, and complicated struggles for citizenship, civil rights, suffrage extension, and political power will take place, marked by splits within groups always thought of as monolithic, alliances of political convenience that produce strange political bedfellows and new cross-cutting cleavages. This is how multicultural democracies emerge, not via blueprints and dramatic constitutional agreements.

\section{A New Paradigm}

After the non-deal "deal of the century," Palestinians, Israelis, and observers are finally being forced to think about how that process can be encouraged. Indeed, the end of hoping for a real two-state solution actually itself solves many problems and opens up many new opportunities for advancing the interests of Jews and Arabs. I am not talking about a "onestate solution." Just because there is no path available to a negotiated two-state solution does not mean that there is a path to some other negotiated solution. Often, and perhaps almost always with protracted ethnonational and racial conflicts, negotiations do not yield results both sides are happy with, or can even live with. Instead, political outcomes, marked not by permanent arrangements but by new battles between new alliances of groups, materialize over very long periods of time and according to 
should focus on how, even over generations, to achieve equality between Jews and Palestinians in the one state -Israel- that does exist. The cost of not doing so is to abet the anti-democratic and racist forces in Israel who want to dominate the entire country, deprive Arabs of any meaningful political opportunities, and use immiseration and intimidation to drive Palestinians out, all without having to say that they are doing so.

Sadly, a negotiated two-state solution is no longer possible. Its slow-boiled death has long been manifest in the shifting terms of debate. Even its diehard promoters long ago stopped advancing specific plans for moving toward trading territory for peace. For years, they have been on the defensive, desperately struggling to replace old maps of what could have been with new maps of what, despite settlement expansion and changing dimensions of Israel's "national consensus": still, perhaps, eventually, could be. Meanwhile the right wing, freed of the need to decry the dangers of trading territory for peace, because the possibility of doing so seems so utterly remote, has shifted attention to paving the way for annexation, in one form or another.

\section{The Right Wing Vision}

The shifted focus of the Israeli right, and of the government it controls, on how to proceed with annexation, rather than how to prevent withdrawal, has resulted in extravagant propaganda efforts that have
Annexation would create a

political arena of immense potential, transforming politics from a zero-sum struggle between Israeli Jews and Palestinians to a more complicated and potentially more productive competition among different Palestinian and Jewish groups

persuaded most settlers and their supporters, along with many middle-of-the-road Israelis, to believe that there are far fewer Palestinians living the West Bank than there actually are -that the doves in Israel's central bureau of statistics and their counterparts in the Palestinian $\mathrm{Na}$ tional Authority have conspired to inflate Palestinian population figures to dissuade Israel from pursuing permanent rule of all of the Land of Israel. These same propaganda outlets seek to reassure Israelis about Israel's capacity permanently to absorb the West Bank by pushing images of rising Jewish birth rates and a flood of Jewish immigrants prompted by what they hope is a renewed wave of anti-Semitism in Europe and America.

A background theme among pundits and activists on the Israeli right has been to adumbrate, however vaguely, how Israel could incorporate the West Bank (and Gaza) with- 


\section{As long as negotiation of}

a two-state solution was

plausible, the argument that

Israel could remain a "Jewish

state" only by withdrawing

from the Palestinian West

Bank and Gaza Strip was

crucial as a way to attract

support from Israeli Jews for

territorial compromise out threatening Jewish control of the country. Most of these schemes are far-fetched - for example, imagining that Egypt and Jordan will accept responsibility for Palestinians living in those areas, and/or transfer them out of Palestine. Others are disingenuous, offering equal citizenship to any Arabs who choose to remain in the expanded Jewish state, as long as they can meet a long list of virtually impossible requirements.

In 2017, however, the President of Israel, Reuven Rivlin -a life-long disciple Vladimir Jabotinsky (the teacher of Menachem Begin) a veteran leader of the Likud and former Speaker of the Israeli Parliament- proposed real annexation, with equal rights to be accorded to all inhabitants. Rivlin made his remarks to a large meeting of settlers and their supporters. He was outraged at legislation intended to legalize thousands of settler housing units on privately owned Palestinian
Arab land, and at the signal sent by some Likud ministers that such discriminatory legislation would be the route followed by Israel to achieve its long-term objectives toward the West Bank.

To preserve the democratic values and honor of the state, and to insure the permanence of Israel's incorporation of the entire Land of Israel, Rivlin called for outright annexation of the West Bank, including the granting of full and equal citizenship to all its Palestinian inhabitants-more or less exactly what Israel did when it transformed areas in the Galilee and elsewhere that it had declared as occupied in 1948 into full and equal parts of the State of Israel, imposing Israeli citizenship on all inhabitants, including Arabs. "Today it is impossible," declared Rivlin,

to avoid the question of whether Israel desires to annex Judea and Samaria... we are now at the moment of truth, the time at which we must determine and understand that international law applies also to us, and as a result we must decide regarding the application of Israeli law. ...I believe that all of Zion is ours and that the sovereignty of the State of Israel should be applied to every single piece of the Land. The imposition of sovereignty over a territory begins with the grant of equal citizenship to all who inhabit the territory, without exception. There cannot be one law for the Israeli and another one for the non-Israeli. When I say that my faith is directed to all of our Zion, that is precisely what I 
mean. The sovereignty of the State of Israel must be established over all of Zion and over all its inhabitants. In one piece of land there cannot be one law for the Israeli and another law for the non-Israeli - for all, the same law. ${ }^{2}$

An unequivocal act of annexation is not about to occur, but the judgments by increasing numbers of influential Israelis that annexation can and should be accomplished is significant. They may think it can occur without producing a transformation in the character of the State of Israel. They are wrong. Yet that error may be father to the act, and grandfather to the transformation of the country. For though it would not create warm and fuzzy feelings among Jews and Arabs, and though it is unlikely that equal citizenship would be granted quickly to all, or even most Arab inhabitants, annexation would create a political arena of immense potential, transforming politics from a zero-sum struggle between Israeli Jews and Palestinians to a more complicated and potentially more productive competition among different Palestinian and Jewish groups searching, within and across the boundaries of their national communities, for political allies and power.

It would take decades for the ensuing struggles to result in the expansion of citizenship and suffrage for all. But that would occur, not least because substantial numbers of Jews would eventually find it in their political interest to join with Arab citizens to support suffrage extension to all those ruled by the state. The mixed governments that would arise from a citizenry comprised of millions of Jews, millions of Arabs, and hundreds of thousands of non-Jewish non-Arabs, all divided into religious, ideological, regional and economic factions, would face enormous challenges. But with the likely enthusiastic support of the international community, new ways forward would also become available.

\section{Conclusion}

It is too soon to speak of such a move as a solution. Nevertheless, it is only by honoring democratic principles and the equal legitimacy of Jewish and Palestinian political aspirations that Israelis and Palestinians will eventually be able to trade the problems they face today for better problems in the future. Most of these opportunities will be in the hands of Palestinians and Jews, compelled by circumstances to find allies across the ethnonational divide with whom to address problems impossible to cope with otherwise. Already, Jews across the Israeli spectrum have been forced to realize that Arabs are central to Israeli politics. The Arab dominated "Joint List" is now Israel's third largest political party. The left knows it cannot regain power without Arab votes and recognition of that party or its supporters as legitimate political partners. The right knows that the left could only threaten its dominance with the help of Arab votes, and thus becomes more explicitly racist in its campaign to suppress Arab voting 


\section{Given that domestic politics} will almost always dominate American policy toward Israel and Palestine, Washington can make its best contribution by backing away from diplomacy and territorial schemes of pseudo separation between Palestinians and Israelis
For its part, Washington must come to terms with the fact that its policies of unlimited political, military, and economic support for Israeli governments not only compromised all diplomatic efforts, but effectively subsidized right-wing maximalism in Israel. Given that domestic politics will almost always dominate American policy toward Israel and Palestine, Washington can make its best contribution by backing away from diplomacy and territorial schemes of pseudo separation between Palestinians and Israelis. Remembering that occupations can end by either withdrawal of the occupier or by full and equal incorporation of the occupied, Americans can work toward that end by holding Israel to standards of equality, democracy, and the fundamental principle that governments can only rule legitimately when they rule through the consent and with the participation of all those they govern.

\section{Endnotes}

1. For the full version of the argument contained in this article, please see the author's latest book, Paradigm Lost: From Two-State Solution to OneState Reality.

2. Speech delivered in Jerusalem on February 13, 2017. Translated from Hebrew by the author from a press release issued by the Office of the President. The document was subsequently removed from the Office's website. Rivlin's position was widely reported in the Israeli press. See, Ian S. Lustick, Paradigm Lost: From Two-State Solution to One-State Reality, (Philadelphia: University of Pennsylvania Press, 2019) pp. 136, 189. 